\title{
The Cointegration Analysis on the Spot Prices of the Malaysian Crude Palm Oil Futures Market
}

\author{
Nik Muhammad Naziman Ab Rahman \\ Correspondence: Nik Muhammad Naziman, Faculty of Business Administration, University Technology MARA \\ (UiTM) Kelantan, Malaysia. E-mail: naziman925@kelantan.uitm.edu.my
}

Received: May 1, 2010

doi:10.5539/ijef.v4n7p95

\author{
Accepted: May 14, 2012 \\ URL: http://dx.doi.org/10.5539/ijef.v4n7p95
}

\begin{abstract}
Futures markets play an important role in the price discovery and forward pricing of agricultural commodities. The analysis of this study has mainly focused on the empirical test of the effect of production, stock and export variables on the prices of the Malaysian Crude Palm oil futures market. For the empirical work, correlation analysis, multiple regression and recent econometric analysis were conducted to determine the price relationships of the Malaysian Crude Palm oil futures markets with the production, stock and export variables. Order of integration for all the variables was checked using Augmented Dickey-Fuller and Phillips-Perron tests of unit root. The Johansen approach was used to test cointegration in multivariate system that involved long run and short run estimations. The Vector Error Correction Model was used to test for causal relationships. The empirical evidence obtained from the study shows there exist a significant long run and short run relationships between the cash and future prices of the Malaysian Crude Palm oil futures market with the production, stock and export variables. The results of the causality test also shows that there is a strong relationship between the Malaysian Crude Palm oil futures market with the production, stock and export variables This mean that any information flow regarding the price movement of the Malaysian Crude Palm oil futures market will affect the production, stock and export variables and vice-versa.
\end{abstract}

Keywords: price discovery, hedging, cointegration

\section{Introduction}

Palm oil is currently the second most important vegetable oil in the world oils and facts market, accounting for $14.35 \%$ of world production of seventeen major oils and facts, ranking only behind soya bean oil, which contributed $20.23 \%$ of world output. In terms of world exports of oils and facts, palm oil is currently leading with a market share of $32 \%$ while soya bean oil has a share of $16.2 \%$. Palm oil and palm kernel oil have become the production growth leaders in the oils and facts complex since the early seventies (Mielke, 1991).

The volume of crude palm oil (CPO) futures on the Kuala Lumpur Commodity Exchange (KLCE) or now on MDEX is slightly more than the production of the Malaysia palm oil. As the price of a palm oil is dependent on its consumption and the level of the stock, it is important to analyze these two variables simultaneously. The world stock/usage of palm oil usually higher than that of Malaysia, not only because of the large stocks in transshipment centers such as Singapore and Rotterdam, but also because some consuming countries prefer to keep relatively large stocks (Mielke, 1991). It has become a common practice among major industrialized countries to use buffer stocks to stabilize the prices of agricultural commodities in the world market (Sarasorro, 1988), including palm oil.

Studies in agricultural economics have shows that the fluctuation of commodities prices is significant and persistent (Wilkinson, 1976) (Brendt,1985). According to Mad Nasir and Fatimah (1992), two of the salient features of agricultural commodities are the volatility and variability in prices. As far as volatility and variability of prices are concerned, the impact is more remarkable in the vegetable oils and fats market, notably palm oil, which is the most widely consumed edible oil in the world. If producers are in fact using futures prices as expected output prices when allocating resources, an assessment of the quality of the prices is important. Thus studies on the efficiency of futures markets have important implications on the issue of whether economics resources are being optimally allocated in the agricultural sector.

It is particularly important to assess the Malaysian Derivatives Exchange (MDEX) market since it is the only futures market for palm oil and producers and other market intermediaries use it as a price indicator. The existence of pricing efficiency in the markets will assume that futures prices move in lines with cash prices in the long-term and that they do not deviate from cash prices for long periods of time. 
The major objective of this studies is to examine empirically the price relationships and the direction of information flow between the Malaysian crude palm oil futures market and the production, stock, export variables.

\subsection{Review of Related Literature}

There has been substantial empirical work, which has investigated the efficiency issue by testing the random walk model. Some of this work rejected the random walk hypothesis, for example, Stevenson and Bear (1970), Cargill and Rausser (1975), and Barnhart (1984); other studies accepted the hypothesis, for example, Larson (1960). Kamara (1982) noted that most of these studies found some evidence of serial correlation in futures prices in the short-run, but the evidence is not strong, and the result depend heavily on the technique as well as the sample period of the studies

Fatimah and Zainalabidin (1991) compared the forecasting performance of crude palm oil (CPO) futures on the KLCE to forecast generated from several other models, i.e., moving average, exponential smoothing, Box-Jenkins and econometric models. They concluded that the futures market does not show any significant inefficiency. Using the RMSE, RMPE and U-statistic to compare the performance of the various models, they found that the futures market fared fairly well in comparison with other models. Only the Box-Jenkins model outperformed the futures market, but the main weakness of this method was its inability to provide an economic explanation for its forecasts.

As cited by Liew and Brooks (1995) that Kok and Goh's (1994) study the random walk hypothesis in the Kuala Lumpur crude palm oil futures market, their results fail to find strong evidence against the random walk hypothesis.

Mohammad Haji Alias and Jamal Othman (1997) used bivariate cointegration technique to determine the long-run relationship of palm oil price and the soybean oil price. Using quarterly data from 1980 through 1995 and Dickey-Fuller and augmented Dickey-Fuller to test for stationarity. The results showed that the time series on palm oil and soybean oil prices are cointegrated and each time series is non-stationary.

A.D Owen et al (1997) examine five major international traded oils: coconut, palm, palm kernel, soybean and sunflower to investigate the price interrelationships in the vegetable and tropical oils market whether they are cointegrated or not. Using monthly data from 1971 through 1993, a vector autoregressive approach to test for cointegration and augmented Dickey-Fuller and Phillips-Perron to test for unit root. The results showed that the relationships were not found to be strong enough to label them as cointegrated series.

Mukesh Chaudhry and Rohan Christie-David (1998) investigates the long-run stochastic properties of informationally linked futures contracts in diverge groups such as soft commodities, grain and oil seeds, livestock, precious metals, energy, foreign currencies, and interest-rate instruments. Using the Phillips-Perron test for unit root and Johansen's test for cointegration to analyse the monthly data covers the period July 1986 through March 1995. The results showed that most futures in the sample exhibit the presence of non-stationarity. The test for cointegration within groups provides strong evidence for soft commodities, precious metals, energy, and short-term interest rates. Weaker evidence for grains and oil seeds and livestock while foreign currency and long-term interest rate futures show evidence of segmentation.

\section{Methodology}

There are several unit root tests available in the literature to determine the order of integration of the individual series. However, the most widely used methods are Augmented Dickey Fuller test (ADF) which was proposed by Said and Dickey (1984) and Phillips and Perron test (PP) by Phillips and Perron (1988). In this study both the ADF and the PP are utilised in the analysis since Schwert (1987) has noted that the ADF statistics may reject the null hypothesis of unit root too often in the presence of the first order moving average process. However, recently Campbell and Perron (1991) have also shown that the ADF class of statistics has better small-sample properties.

Once we determine the order of integration of each series, the next step is to test for cointegration relationships among the series. The Johansen-Juselius is based on maximum-likelihood estimation is designed to test a number of linearly independent cointegrating vectors existing among the variables. The model also utilises the likelihood ratio test statistic that has an exact limiting distribution, which can be used to estimate cointegration relationships among a group of two or more variables. Besides it can estimate a number of linearly independent vectors, Perman (1991) pointed out that the advantage of Johansen-Juselius approach over E-G approach is that the procedure allows testing for linear restriction on the cointegrating parameters. The test statistic in the Johansen and Juselius also can be compared to known critical values.

The likelihood-ratio test of the null hypothesis is obtained by the trace test defined as; 


$$
\text { Trace Tests }=-T \sum_{i=r+1}^{p} \ln \left(1-Q_{i}^{2}\right)
$$

where $T$ is the number of time period available in the data. The null hypothesis for trace test is that whether there are $r$ or less cointegrating vector. The null of $\mathrm{r}=0$ is test against the general hypothesis of $\mathrm{r} \leq 1, \mathrm{r} \leq \mathrm{p}$. Equivalently we can also use the maximal eigenvalue test. The test is that there are $r$-cointegrating vectors in a set of $\mathrm{p}$ variables against $r+1$. In other words, the null of $r=0$ is test against the specific hypothesis of $r=1, r=p$. It is defined as;

$$
\text { Maximal Eigenvalue Tests }=-T \ln \left(1-Q_{r+1}^{2}\right)
$$

The test statistics of the trace and maximum eigenvalues may be compared with the critical values provided by Osterwald-Lenum (1992).

$$
\left(\begin{array}{c}
\triangle S P T \\
\triangle P R O D \\
\triangle S T O C K \\
\triangle E X P O R T
\end{array}\right)=\sum_{i=1}^{k}\left(\Gamma_{i}\right)\left(\begin{array}{c}
\Delta S P T \\
\triangle P R O D \\
\Delta S T O C K \\
\triangle E X P O R T
\end{array}\right)+(\Pi)\left(\begin{array}{c}
S P T \\
P R O D \\
S T O C K \\
\text { EXPORT }
\end{array}\right)+\left(\begin{array}{c}
\mu_{1} \\
\mu_{2} \\
\mu_{3} \\
\mu_{4}
\end{array}\right)+\left(\begin{array}{c}
\varepsilon_{1} \\
\varepsilon_{2} \\
\varepsilon_{3} \\
\varepsilon_{4}
\end{array}\right)
$$

Attaining the long run estimates of the cointegration relationships is only half of the whole process of cointegration in multivariate systems. Estimating the short run model of spot prices of Malaysian crude palm oil and the international competiting oils market is another important part of the analysis in order to capture the short run adjustment behaviour of economic variables, which is quite relevant to policy implications. The number of cointegrating vectors, which is revealed from the results of Johansen's tests, will determine the approach of estimating the short run model of spot prices of Malaysian crude palm oil futures market and spot prices of international competitive oils. When there is only one cointegrating vector, the short run dynamics of spot prices of Malaysian crude palm oil and the international competiting oils functions can be estimated using the (single equation) general to specific procedure. The technique departs from the general autoregressive distributed lag representation with error correction term(s) or EC obtained from the relevant estimated cointegrating vector(s):

$$
A(L) \Delta S P T_{t}=\alpha_{0}+B(L) \triangle L P R O D_{t}+C(L) \Delta L S T O C K_{t}+D(L) \Delta L E X P O R T_{t}+\alpha_{1} E C_{t-1}
$$

where $\mathrm{SPT}_{\mathrm{t}}$ is spot price while $A(L) \ldots D(L)$ are lag polynomials. The equation can be estimated using ordinary least square (OLS) if all of the independent variables are weakly exogenous, however, when one or some of the independent variables are not weakly exogenous, the function needs to be estimated using Instrumental Variables (IV) technique.

\subsection{Data Used in the Study}

The data in this study consist of the spot prices of the Malaysian crude palm oil are collected from MPOB (Malaysian Palm Oil Board) for contracts maturing at each month from Jan 1998 to Dec. 2010, providing a total of 192 observations. Consecutively, the fundamental factors i.e; the closing stock (STOCK), production (PROD), export (EXPORT), and the spot prices (SPT) of the Malaysian crude palm oil futures market are gathered from the same period from PORLA Update Report.

\section{Empirical Results}

Results of unit root test in level and first difference are presented in Table 1. The computed values of statistics in both time periods are all insignificant at the five percent significance level for both ADF and PP tests. The results fail to reject the null hypothesis of unit roots in their level form in the autoregressive representation of the price series, that is, they are all not I(0). Thus, implying that there is no possibility of the series to be stationary around a constant mean or around deterministic linear trend.

Unit root tests on the first difference on all series were also conducted. Table 1 shows the values of statistics for both sub-periods are significant at the one percent level. Indicating the rejection of null hypothesis of the existence of a unit root for each of the price series in their first difference. Thus all the prices series needed to be differenced once in order to achieve stationarity and they are confirmed to be integrated of order one. The standard cointegration model requires that all variables included in the regression must be of the same order of integration. 
Table 1. Results of Phillips-Perron and (Augmented) Dickey Fuller Unit Root Tests for Spot Prices of Malaysian Crude Palm Oil Futures Market, Production, Stock, Export

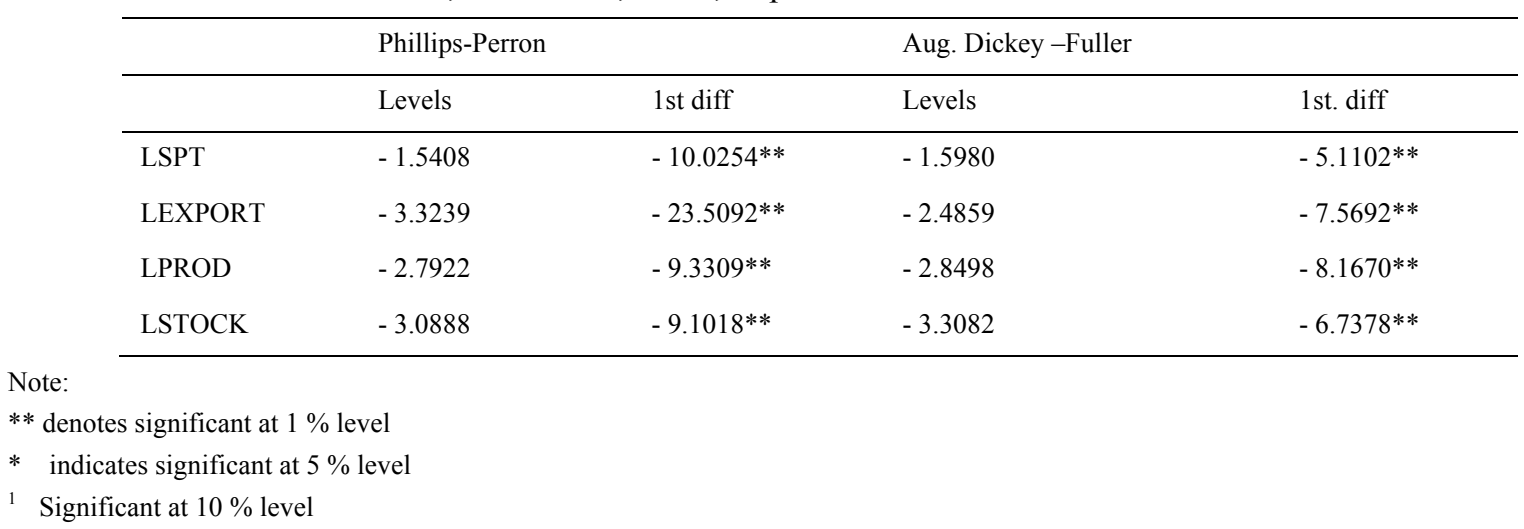

The above Phillips-Perron and Aug. Dickey-Fuller test statistics are compared to the MacKinnon (1990) critical values for rejection of hypothesis of a unit root. Unlike the ADF test, there are no truncation lagged difference terms. Instead of specifying the number of lagged difference terms, the truncation lag for the Newey-West correction is specified, that is, the number of periods of serial correlation to be included. The equation is estimated using ordinary least squares (with the optional inclusion of constant and time trend) and then the t-statistic of the coefficient is corrected for serial correlation in $\mathrm{t}$.

The results of the application of the Johansen technique to the identification of long run relationships between the Spot price of the Malaysian crude palm oil futures market and export, production and stock level can be seen in Table 2. We assume that there is no deterministic trend in data, no intercept or trend in the cointegrating equation. Result of Johansen's test suggests that one cointegrating vector exists based upon the $\lambda_{\max }$ test at $1 \%$ level (Panel I). The trace statistic suggests rejection of one cointegration vector at $1 \%$ level. The cointegrating vector was estimated with a provision for 10 lags and we found no serious serial correlation and no normality problem with the inclusion of this number of lags except for production variable (Panel V). The estimated cointegrating vector has theoretically plausible coefficients (Panel II). The results of tests for weak exogeneity are consistent with the information on the values of alpha $(\alpha)$ or speed of adjustment's coefficients and their respective standard errors in Panel III(Note 1). The test of weak exogeneity reveals that production appears to be weakly exogeneous at a marginal level of significant at $66.24 \%$ (Panel VI). Imposing restrictions on the independent variables do not seem to be valid. Thus our restricted cointegrating equation remains similar to the unrestricted one. The following is the estimated of the long run Spot prices of the Malaysian crude palm oil futures market and production, stock and exports function;

$$
L S P T_{t}=159.46 L_{E X P O R T}-130.34 L P R O D_{t}-9.42 L_{S T O C K_{t}}
$$

The above equation indicates that export is positively impact with estimated elasticity of 159.46 . It is also shown that in the long run is negatively influenced the production and stock variables estimated elasticities of -130.34 and -9.42 respectively.

Since the outcome of Johansen's test shows that there is only one cointegrating vector, we estimate the short run model using the single equation generalized unrestricted model (GUM) applying the instrumental variable (IV) technique. The short run parsimonious Spot price of the Malaysian crude palm oil futures market and the production, stock and exports function can be seen in Table 3. Estimate of attached error correction term indicates that the speed of adjustment to long run changes are quite slow $(-0.0315)$ is significant at $5 \%$ level. Despite the significant reduction in the parameters (from 46 to 31 variables) our final specifications still maintain superiority over the initial largely parameterized model in terms of standard error of regression and explanatory power. Generally, the estimated coefficients are significant and except for the $\chi^{2}$ values of the Breusch-Godfrey serial correlation LM test (lag 4), the estimated equations could pass the battery of diagnostic tests for autocorrelation, autoregressive conditional heteroscedasticity (ARCH test), normality of residuals, tests for functional form misspecifications and joint significance of all the explanatory variables. 
Table 2. Results of Johansen Procedure for Cash Price of Malaysian crude palm oil futures Market, Export, Production and Stock, VAR with 10 lags. Sample period: 1998-2010 (192 observations)

Eigenvalues: $\begin{array}{llll}0.302 & 0.095 & 0.025 & 0.003\end{array}$

Test Statistics For The Number of Co-Integrating Vectors:

\begin{tabular}{cccccccc}
\hline \multicolumn{9}{c}{$\lambda$ max } & \multicolumn{3}{c}{ Trace } \\
\hline Ho:rank= r & T & T-nk & $\mathbf{9 5 \%}$ & T & T-nk & $\mathbf{9 5 \%}$ \\
\hline $\mathrm{r}=0$ & $52.4^{* *}$ & $38.05^{* *}$ & 27.1 & $171.19^{* *}$ & $51.68^{* *}$ & 47.2 \\
$\mathrm{r} \quad 1$ & 14.58 & 10.59 & 21.0 & 18.78 & 13.64 & 29.7 \\
$\mathrm{r} \quad 2$ & 3.75 & 2.72 & 14.1 & 4.20 & 3.05 & 15.4 \\
$\mathrm{r} \leq 3$ & 0.44 & 0.32 & 3.8 & 0.44 & 0.32 & 3.8 \\
\hline
\end{tabular}

II. Estimated Co-Integrating Vector

\begin{tabular}{llll}
\hline LSPT & LEXPORT & LPROD & LSTOCK \\
\hline 1.0000 & -159.46 & 130.34 & 9.42 \\
\hline
\end{tabular}

III. Estimated Adjustment Matrix

\begin{tabular}{llll}
\hline LSPT & LEXPORT & LPROD & LSTOCK \\
\hline $\mathbf{0 . 0 0 7 7}$ & -0.0008 & 0.0078 & 0.0034 \\
$\{0.0017\}$ & $\{0.0023\}$ & $\{0.0021\}$ & $\{0.0026$ \\
\hline
\end{tabular}

IV. Restricted Co-Integrating Vector

\begin{tabular}{llll}
\hline LSPT & LEXPORT & LPROD & LSTOCK \\
\hline 1.0000 & -120.78 & 98.56 & 6.94 \\
\hline
\end{tabular}

V. Test for Appropriate Lag Length (10)

\begin{tabular}{|c|c|c|c|c|}
\hline Serial : & LSPT & LEXPORT & LPROD & LSTOCK \\
\hline \multicolumn{5}{|c|}{ CORRELATION } \\
\hline$\chi^{2}(7)$ & $10.95[0.14]$ & $11.11[0.13]$ & $31.05[0.00]^{* *}$ & $12.95[0.07]$ \\
\hline$F(7,98)$ & $1.13[0.34]$ & $1.15[0.33$ & $3.78[0.00]^{* *}$ & $1.36[0.22]$ \\
\hline \multicolumn{5}{|l|}{ Normality: } \\
\hline$\chi^{2}(2)$ & $0.76[0.68]$ & $0.98[0.60]$ & $21.25[0.00]^{* *}$ & $9.18[0.01]^{*}$ \\
\hline \multicolumn{5}{|l|}{$\operatorname{ARCH} \chi^{2}(7)$} \\
\hline & $3.58[0.82]$ & $2.86[0.89]$ & $12.59[0.08]$ & $12.62[0.81]$ \\
\hline \multicolumn{5}{|l|}{$\operatorname{ARCH}(7,61)$} \\
\hline & $0.34[0.93]$ & $0.27[0.96]$ & $1.29[0.26]$ & $1.29[0.26]$ \\
\hline
\end{tabular}

Exogeneity Tests (Lprod Weakly Exogenous)

\begin{tabular}{llllll}
\hline Ho: & $\alpha_{2}=\alpha_{3}=\alpha_{4}=\alpha_{5}=\alpha_{6}=0$ & & $\chi^{2}{ }_{0.05}$ & with 3 d.f. $=40.902[0.0000]^{* *}$ \\
Ho: & $\alpha_{2}=0$ & & $\chi^{2}{ }_{0.05}$ & with 1 d.f. $=$ & $14.072[0.0002]^{* *}$ \\
Ho: & $\alpha_{3}=0$ & & $\chi^{2}{ }_{0.05}$ & with 1 d.f. $=$ & $0.190[0.6624]$ \\
Ho: & $\alpha_{4}=0$ & $\chi_{0.05}^{2}$ & with 1 d.f. $=$ & $10.024[0.0015]^{* *}$ \\
\hline
\end{tabular}

Note:

** denotes significant at $1 \%$ level.

*indicates significant at $5 \%$ level.

Figures in square parentheses [ ] refer to marginal significance level.

Figures in \{\} refer to standard errors of alpha's (speed of adjustment) coefficients. 
Table 3. Results of Short Run Reduced Form GUM -TSLS for Cash Price of Malaysian Crude Palm Oil Futures Market, Export, Production and Stock

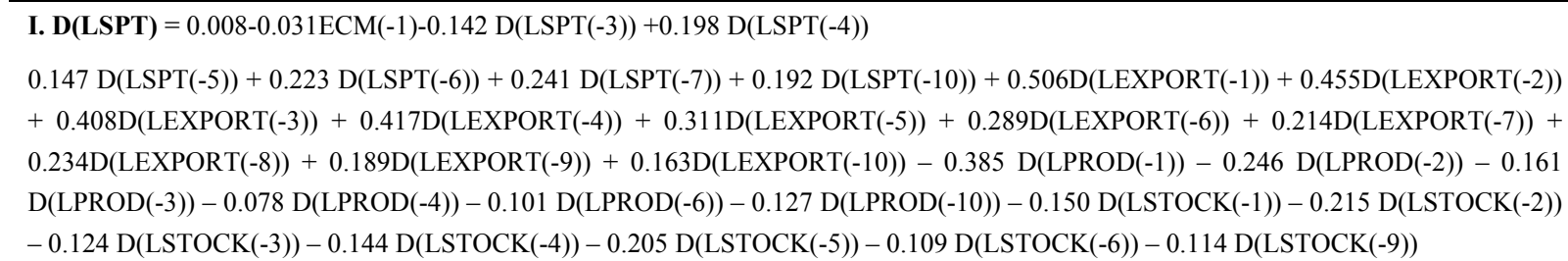

\begin{tabular}{|c|c|c|c|c|}
\hline Variable & Coefficient & Std. Error & t-Statistic & Prob. \\
\hline $\mathrm{C}$ & 0.008420 & 0.007421 & 1.134606 & 0.2589 \\
\hline $\operatorname{ECM}(-1)$ & -0.031500 & 0.015005 & $-2.099291 *$ & 0.0380 \\
\hline $\mathrm{D}(\operatorname{LSPT}(-3))$ & -0.142182 & 0.095574 & -1.487668 & 0.1396 \\
\hline D(LSPT(-4)) & 0.198438 & 0.099019 & $2.004033^{*}$ & 0.0475 \\
\hline $\mathrm{D}(\operatorname{LSPT}(-5))$ & 0.147076 & 0.090684 & 1.621854 & 0.1076 \\
\hline D(LSPT(-6)) & 0.223142 & 0.092493 & $2.412523 *$ & 0.0175 \\
\hline D(LSPT(-7)) & 0.241702 & 0.093094 & $2.596312 *$ & 0.0107 \\
\hline D(LSPT(-10)) & 0.192757 & 0.084235 & $2.288322 *$ & 0.0240 \\
\hline D(LEXPORT(-1)) & 0.506682 & 0.126687 & $3.999488 * *$ & 0.0001 \\
\hline D(LEXPORT(-2)) & 0.455055 & 0.125987 & $3.611925^{* *}$ & 0.0005 \\
\hline D(LEXPORT(-3)) & 0.408716 & 0.120958 & $3.378979 * *$ & 0.0010 \\
\hline D(LEXPORT(-4)) & 0.417245 & 0.107926 & $3.866037 * *$ & 0.0002 \\
\hline D(LEXPORT(-5)) & 0.311241 & 0.089851 & $3.463977 * *$ & 0.0008 \\
\hline D(LEXPORT(-6)) & 0.289117 & 0.084074 & $3.438825^{* *}$ & 0.0008 \\
\hline D(LEXPORT(-7)) & 0.214494 & 0.074779 & $2.868364 * *$ & 0.0049 \\
\hline D(LEXPORT(-8)) & 0.234083 & 0.071595 & $3.269543^{* *}$ & 0.0014 \\
\hline D(LEXPORT(-9)) & 0.189997 & 0.065608 & $2.895936^{* *}$ & 0.0045 \\
\hline D(LEXPORT(-10)) & 0.163238 & 0.061101 & $2.671618^{* *}$ & 0.0087 \\
\hline D(LPROD(-1) & -0.385499 & 0.106664 & $-3.614130 * *$ & 0.0005 \\
\hline $\mathrm{D}(\operatorname{LPROD}(-2))$ & -0.246129 & 0.100663 & $-2.445080 *$ & 0.0160 \\
\hline D(LPROD(-3) & -0.161272 & 0.094131 & -1.713271 & 0.0894 \\
\hline D(LPROD(-4)) & -0.078244 & 0.077487 & -1.009765 & 0.3148 \\
\hline D(LPROD(-6)) & -0.101888 & 0.069897 & -1.457684 & 0.1477 \\
\hline D(LPROD(-10)) & -0.127918 & 0.066792 & -1.915174 & 0.0580 \\
\hline D(LSTOCK(-1)) & -0.150768 & 0.071668 & $-2.103697^{*}$ & 0.0376 \\
\hline D(LSTOCK(-2)) & -0.215719 & 0.071899 & $-3.000317 * *$ & 0.0033 \\
\hline D(LSTOCK $(-3))$ & -0.124402 & 0.072017 & -1.727398 & 0.0868 \\
\hline D(LSTOCK(-4)) & -0.144155 & 0.072234 & $-1.995669^{*}$ & 0.0484 \\
\hline D(LSTOCK(-5)) & -0.205246 & 0.073889 & $-2.777755^{* *}$ & 0.0064 \\
\hline D(LSTOCK(-6)) & -0.109448 & 0.067764 & -1.615134 & 0.1091 \\
\hline D(LSTOCK(-9)) & -0.114968 & 0.061020 & -1.884111 & 0.0621 \\
\hline \multirow[t]{2}{*}{ Adjusted R-squared } & 0.2594 & S.E. of regression & 0.0662 & \\
\hline & $2.6703 * *$ & Prob(F-statistic) & 0.0000 & \\
\hline
\end{tabular}

III. Autocorr (Breusch-Godfrey Serial Correlation LM Test):

$\chi^{2}(1)=0.6911[0.405] \quad \chi^{2}(2)=1.4778[0.477]$ 


\begin{tabular}{lll}
\hline$\chi^{2}(3)=$ & $1.4778[0.477]$ & $\chi^{2}(4)=11.8052[0.018]^{*}$ \\
$\mathrm{~F}(1)=$ & $0.5401[0.463]$ & $\mathrm{F}(2)=0.5754[0.564]$ \\
$\mathrm{F}(3)=$ & $0.5754[0.564]$ & $\mathrm{F}(4)=2.4334[0.051]$
\end{tabular}

Normality: $\quad \chi^{2}(2)=0.1622[0.5727]$

ARCH:

$$
\begin{aligned}
& \chi^{2}(1)=3.3395[0.067] \\
& \chi^{2}(3)=4.5617[0.206] \\
& \mathrm{F}(1)=3.3716[0.068] \\
& \mathrm{F}(3)=1.5268[0.210]
\end{aligned}
$$$$
\chi^{2}(2)=4.3209[0.115]
$$$$
\chi^{2}(4)=2.6318[0.621]
$$$$
\mathrm{F}(2)=2.1812[0.116]
$$$$
\mathrm{F}(4)=0.6466[0.630]
$$

Functional Form: Number of fitted terms $=1$ :

F-statistics 0.4264 [0.5150]

IV. Instruments: C ECM(-1) D(LPROD) D(LSPT(-1)) D(LSPT(-2)) D(LSPT(-3)) D(LSPT(-4)) D(LSPT(-5)) D(LSPT(-6)) D(LSPT(-7)) $\mathrm{D}($ LSPT(-10)) $\quad \mathrm{D}($ LEXPORT(-1)) $\quad \mathrm{D}($ LEXPORT(-2)) $\quad \mathrm{D}($ LEXPORT(-3)) $\quad \mathrm{D}(\operatorname{LEXPORT}(-4)) \quad \mathrm{D}(\operatorname{LEXPORT}(-5)) \mathrm{D}(\operatorname{LEXPORT}(-6))$ D(LEXPORT(-7)) D(LEXPORT(-8)) D(LEXPORT(-9)) D(LEXPORT(-10)) D(LPROD(-1))D(LPROD(-2)) D(LPROD(-3)) D(LPROD(-4)) D(LPROD(-6)) D(LPROD(-10)) D(LSTOCK(-1)) D(LSTOCK(-2))D(LSTOCK(-3)) D(LSTOCK(-4)) D(LSTOCK(-5)) D(LSTOCK(-6)) D(LSTOCK(-7)) D(LSTOCK(-9))D(LSTOCK(-10)) D(LPROD(-11)) D(LSTOCK(-11)) D(LSPT(-11))

\begin{tabular}{llll}
\hline V. Information On The Full Unreduced Model: (46 parameters) & \\
Adjusted R-squared & 0.0379 & S.E. of regression & 0.0755 \\
F-statistic & $1.5161^{*}$ & Prob (F-statistic) & 0.0455
\end{tabular}

Note:

** denotes significant at $1 \%$ level.

* denotes significant at $5 \%$ level.

Figures in square parentheses [ ] refer to marginal significance level.

This implies that there is a strong long-run relationship between the spot and the futures prices of the Malaysian crude palm oil futures market and the production, stock and export variables for the period under investigation. In other words, the price series are cointegrated. These imply that the Malaysian crude palm futures market are inefficient in relation to the production, stock and export variables.

The results also support the earlier findings of Mielke (1991) and Mad.Nasir and Fatimah (1992) that there are relationship between prices of palm oil with the level of stock, production and export.

To examine the nature of the direction of information flow and the lead-lag relationship between spot prices of the Malaysian crude palm oil futures market with the production, stock and export variables, the Granger causality and vector error correction model (VECM), are used.

Table 4. Causality Results Based on Vector Error-Correction Model (VECM) on Cash Price of Malaysian Crude Palm Oil Futures Market, Production, Export and Stock. 1998-2010

\begin{tabular}{llllllll}
\hline & LSPT & LPROD & LEXP & LSTOCK & ECT[e1,t-1] & A- R $^{2}$ & SE \\
\hline Dep. Variable & \multicolumn{7}{c}{ t-statistics } \\
\hline LSPT & - & $-2.9380^{*}$ & $2.2200^{*}$ & -0.1836 & -0.1061 & 0.0815 & 0.0357 \\
LPROD & $-3.4188^{*}$ & - & $-4.6847^{*}$ & -1.3264 & $3.4495^{*}$ & 0.2180 & 0.0503 \\
LEXP & $-3.1737^{*}$ & -1.4893 & - & 0.7743 & -1.8738 & 0.2494 & 0.0557 \\
LSTK & -0.2956 & -0.3381 & 0.1956 & - & $-6.7920^{*}$ & 0.3603 & 0.1015
\end{tabular}

Note: All variables are in first differences (denoted by $\Delta$ ). VECM was estimated including an optimally determined criteria [Akaike's FPE]. **, and * indicates significance at the 1 percent and 5 percent level.

The VECM results in Table 4, shows that, there is evidence of one cointegrating vectors that signal one error correction term's (ECT) embedded in the system. Secondly, short-run channels of Granger-causality are statistically significant at 5 percent in the price series. These suggest, there is a causal relationship from the spot price to the production and export variables. Thirdly, we find that there is a bidirectional flow of information of between 
production and export variables with the spot price. Meanwhile, we can see that there is a unidirectional flow of information from the export to production variables.

We can conclude from the evidence that the spot prices of the Malaysian crude palm oil futures market has a causal relationship with the export and production level variables.

\section{Concluding Remarks}

The study also proved that the spot prices of the Malaysian crude palm oil market has a stable long-run and short-run relationships with the production, stock and export from the results of Johansen's cointegration and vector error-correction model. This indicates that the production, stock level and export variables plays an important role in influencing the prices of the crude palm oil. These results uphold the previous studies that production; stock level and export variables do influence the prices of the Malaysian crude palm oil futures market and this indicates the existence of inefficient. The study of market efficiency of agricultural futures market has important implications for commodities exchange, policy makers, traders and producers. The most important implication is that a good price transmission system is essential to ensure that future prices do not diverge from fundamentals. The futures market has to be closely related to actual demand and supply conditions in order for futures prices to be good indicators for the cash market. Therefore the government should take great care on the policy of replanting of palm oil trees, so that the production of crude palm oil can be enhance to reflect the price of the crude palm oil. Stock level of palm oil should be maintained in order the supply of palm oil to the market are at a consistent to the needs of the market so that it can be justified to the demand in order to maintained the price of crude palm oils. Being the main producers of the crude palm oils, export of the goods should be monitors so that the stability of the prices can achieved through quotas and negotiations among producing counties like Indonesia, South African countries etc. The commodities exchange should be aware the signals from the production output, stock level and export numbers which can cause an effect on the spot prices of the crude palm oils. Any fluctuations on these variables, thus has to be monitor in order to maintain the market efficiency of the commodities.

The potential uses of these findings are numerous. Hedgers may benefit from this information when deciding upon the appropriate futures contract to be used. They should be aware that any information about the supply conditions of the crude palm oils will have an effect on spot prices, which make it more concern in identifying the appropriate tools to analyse it. The cointegration results imply that it may be possible to hedge whether in the long term or short term in the Malaysian crude palm oil futures market in order to reduce their risks. Investors also have to realise that by hedging in the futures market can benefit them not only reduce losses but can diversify the risk to it. On the other hand, the causal relationships discovered in the studies may be useful to both traders and speculators in using their arbitrage opportunities between the cash (spot) and futures contracts.

\section{Referencess}

Akaike, H. (1977). On Entropy Maximization Principle. In P.R. Krishniah. (Ed.), Application of Statistics. North-Holland, Amsterdam.

Bank Negara Malaysia. (1999). Annual Report. Kuala Lumpur: Bank Negara Malaysia.

Barnhart, S. W. (1984). An Investigation into the Causes of Non-Martingale Behaviour in Commodity Futures Prices. Ph. D. dissertation, Texas: Texas A \& M University.

Brandt, \& Jon, A. (1985). Forecasting and Hedging: An Illustration of Risk Reduction in the Hog Industry. American Journal of Agricultural Economics, February, 24-31.

Burns, J. M. (1983). Futures Markets and Market Efficiency. In Strait, M.E. (Ed.) Futures Market: Modeling, Managing and Monitoring Futures Trading. London: European University Institute, pp. 46-74.

Cargill, T. F., \& Rausser, G. C. (1975). Temporal Price Behaviour in Commodity Futures Markets. Journal of Finance, 30, 1043-1053.

Chaudhry, M., \& Christie-David, R. (1998). Long-Term Structural Price Relationships in Futures Markets. Journal of Derivatives, 45-59. http://dx.doi.org/10.3905/jod.1998.407995

Dickey, D. A., \& Fuller, W. A. (1981). Likelihood Ratio Statistic for Autoregressive Time Series with a Unit Root. Econometrica, 49, 1057-1072. http://dx.doi.org/10.2307/1912517

Fatimah Mohd. Arshad, \& Roslan Abdul Ghafar. (1986). Crude Palm Oil Price Forecasting: Box Jenkings Approach. PERTANIKA, 9(3), 359-367.

Granger, C. W. J. (1986). Developments in the Study of Cointegrated Economic Variables. Oxford Bulletin of Economics and Statistics, 48, 213-228. http://dx.doi.org/10.1111/j.1468-0084.1986.mp48003002.x 
Hawawini, G. (1993). International Finance. Routledge London: Mac-Graw Hill.

Jamal Othman, \& Mohammad Hj. Alias. (1997). Examining Price Responsiveness in US and EU Markets for Malaysian Palm Oil. Malaysian Oil Science and Technology, 6(2), pp. 96-101.

Johansen, S., \& Juselius, K. (1990). Maximum Likelihood Estimation and Inference on Cointegration-with Applications to the Demand for Money. Oxford Bulletin of Economics and Statistics, 52, 169-210. http://dx.doi.org/10.1111/j.1468-0084.1990.mp52002003.x

Kamara, A. (1982). Issues in Futures Markets: A Survey. Journal of Futures Markets, 2(3), 261-294. http://dx.doi.org/10.1002/fut.3990020306

KLCE Crude Palm Oil Futures Market Prices: Market Statistics for the Month. (1985-1997). Malaysia. KLCE.

Kok, K. L., \& Goh, K. L. (1994). Crude Palm Oil Futures Price Behaviour in the Kuala Lumpur Commodity Exchange, Proceedings of the First Annual Conference of the Asia Pasific Finance Association, 1, 32-55.

Larson, A. B. (1960). Measurement of a Random Process in Futures Prices. Food Research Institute Studies, 1(3), 313-324.

Liew, K. Y., \& Brooks, R. D. (1998). Returns and Volatility In The Kuala Lumpur Crude Palm Oil Futures Market. $\begin{array}{lllll}\text { Journal of } & \text { Futures } & \text { Markets, } & \text { 18(8), } & \text { 985-999. }\end{array}$ http://dx.doi.org/10.1002/(SICI)1096-9934(199812)18:8<985::AID-FUT6>3.0.CO;2-5

Mad Nasir Shamsudin, \& Fatimah Mohd Arshad. (1991). Short-term Forecasting of Crude Palm Oil Prices. Paper presented at the PORIM International Palm Oil conference. Palm Oil Research Institute of Malaysia, 9-14 September, Kuala Lumpur.

Mad Nasir Shamsudin, Zainalabidin Mohamed, \& Fatimah Mohd Arshad. (1989). Selected Factors Affecting CPO Prices, Malaysian Journal of Agricultural Economics, 5, Dec, pp. 20-29.

Mad Nasir, Shamsudin, \& Fatimah, Mohd Arshad. (1992). Short Term Forecasting of Crude Palm Oil Prices: Fundamental and Technical Approaches. Paper presented at 1992/93 Palm Oil Outlook Forum, 10 April, Kuala Lumpur, Malaysia.

Mielke, S. (1991). Economic Prospect of Oilseeds, Oils and Fats Towards the $21^{\text {st }}$ Century. Paper presented at the PORIM International Palm Oil Conference. Palm Oil Research Institute of Malaysia, 9-14 September 1991, Kuala Lumpur.

Mielke, S. (1991). The Prospects of Palm Oil, Soybean Oil up to May/June. Oil World, February 22, pp. 1-4.

Mohammad Haji Alias, \& Jamal Othman. (1997). Cointegration Between Palm Oil Price And Soyabean Oil Price: A Study on Market Integration. Malaysian Oil Science and Technology, 6(2), 92-95.

Oil World Annual. (2000). Hamburg: ISTA Mielke GmbH.

Oil World Monthly data. (1985-1997). Hamburg: ISTA Mielke GmbH.

Osterwald-Lenum, M. (1992). A Note with Quantiles of the Asymptotic Distribution of the Maximum Likelihood of Cointegration Rank Statistic. Oxford Bulletin of Economics and Statistics, 54, 461-471. http://dx.doi.org/10.1111/j.1468-0084.1992.tb00013.x

Owen, A. D., Chowdhury, K., \& Garrido, J. R. R. (1997). Price Interrelationships in the Vegetable and Tropical Oils Market. Applied Economics, 29, 119-127. http://dx.doi.org/10.1080/000368497327470

Phillips, P. C. B., \& Perron, P. (1988). Testing for a Unit Root in Time Series Regression. Biometrica, 75, 335-346. http://dx.doi.org/10.1093/biomet/75.2.335

Porla Palm Oil Monthly Data. (1985-1997). Palm Oil Registration and Licensing Authority, Ministry of Primary Industries, Malaysia.

Rausser, G. C., \& Carter, C. (1983). Futures Market Efficiency in the Soyabeans Complex. Review of Economics and Statistics, 65(3), 469-478. http://dx.doi.org/10.2307/1924192

Sarassoro, \& Gboroton F. (1988). International Risk Management: The Case of Cocoa and Coffee in the Ivory Coast, $\mathrm{PhD}$ dissertation, University of Illinois at Urbana-Champaign.

Stevenson, R. A., \& Bear, R. M. (1970). Commodity Futures: Trends Or Random Walk?. Journal of Finance, 25, 65-81.

Wilkinson, M. (1976). Economic Models of Food and Agricultural System: U.S Livestock and Grain Markets. Columbia Journal World of Business, Winter, pp. 46-51. 
Working, H. (1958). A Theory of Anticipatory Prices. American Economic Review, 48, 188-199.

World Bank. (1990). Price Prospects for Major Primary Commodities, 1990-2005, Vol. II.

Notes

Note 1 . Then t-value of the alpha (speed of adjustment) coefficient calculated as a ratio of the coefficient over the standard error can be used as an initial indicator whether an independent variable is weakly exogenous or not. Lower $\mathrm{t}$-value is normally associated with the independent variable being weakly exogenous and vice-versa. 